\title{
Comparison of group cohesion among winners and losers of all india inter university male basketball players
}

\section{POOJA CHOUDHARY}

Received : 10.10.2014; Revised : 04.03.2015; Accepted : 17.03.2015

\section{Author for correspondence}

POOJA CHOUDHARY

Noida College of Physical

Education, Dhoom Manikpur,

Dadri, GAUTAMBUDH NAGAR (U.P.) INDIA

\section{-ABSTRACT}

The purpose of this study was to compare the level of Group Cohesion between Winners (semifinalist) and Losers (loser of quarter-finalist) of All India Inter University Male Basketball Team Championship held at Banaras Hindu University, U.P. For the purpose of this investigation 96 male subjects ( 48 winners and 48 losers players from concern teams) were selected as subjects of the study. Their age were ranged from 18 to 25 years. The Group Enviromental Questionnaire developed by Albert V. Carron was used. Test consist 18 statements of 4 aspects (Attraction of Group Task 4 Statements, Attraction of Group Social 5 Statements, Group Integration Task 5 Statements, Group integration Social 4 Statements). t" test was employed to analyze the data. Result revealed that there was significance difference found between Winners and Losers of All India Inter University Male Basketball Teams in regard to Group Cohesion at 0.05 level of confidence.

- KEY WORDS : Group cohesion, All India inter university, Basketball

- HOW TO CITE THIS PAPER : Choudhary, Pooja (2015). Comparison of group cohesion among winners and losers of all india inter university male basketball players. Internat. J. Phy. Edu., 8 (1) : 32-35. 